IBIMA Publishing

Journal of e-Government Studies and Best Practices

https://ibimapublishing.com/articles/JEGSBP/2018/335906/

Vol. 2018 (2018), Article ID 335906, 14 pages, ISSN : 2155-4137

DOI: $10.5171 / 2018.335906$

Research Article

\title{
Critical Success Factors for e-Government Projects: The case of Botswana
}

\author{
Christopher B. Mokone ${ }^{1}$, Oduronke T. Eyitayo ${ }^{2}$ and Audrey Masizana- Katongo ${ }^{3}$ \\ ${ }^{1}$ Department of Business Technology Management \\ Korea Advanced Institute of Science and Technology \\ Daejeon, South Korea \\ ${ }^{2,3}$ Department of Computer Science, University of Botswana, Gaborone, Botswana
}

Received date: 13 December 2017; Accepted date: 9 August 2018; published date: 24 October 2018

Academic Editor: Samali V. Mlay

Copyright (C) 2018. Christopher B. Mokone, Oduronke T. Eyitayo and Audrey Masizana- Katongo. Distributed under Creative Commons CC-BY 4.0

\begin{abstract}
The research developed critical success factors for e-Government in Botswana. The main research question was "What are the critical success factors for e-Government in Botswana?" To test relevancy of identified factors from the literature, questionnaire and interviews were mixed to collect primary data. The data collection focused on the eGovernment Office and ministries who are key stakeholders in the e-Government service delivery framework. The selected participants included focus group of senior IT officers from all Government ministries. Seven critical success factors were derived as the critical success factors for e-Government in Botswana. Likert scales were used to rank factors identified from the literature review. The success factors are demand side engaging executive management to set a clear vision, prioritizes functional capability and manages stakeholder engagement.
\end{abstract}

Keywords: E-Government, Critical Success Factors, Enterprise Architecture, Botswana

\section{Introduction}

Information systems in general and eGovernment projects in particular, have many diverse and complex challenges that are not easy to overcome (Gil-Garci'a \&
Pardo, 2005). The fact that systems are interconnected in e-Government poses a unique challenge for implementation because requirements stretch across different departments or agencies (Saha, 2009, 2010a, 2010b). Indeed, successful

Cite this Article as: Christopher B. Mokone, Oduronke T. Eyitayo and Audrey Masizana- Katongo (2018)," Critical Success Factors for e-Government Projects: The case of Botswana ", Journal of e-Government Studies and Best Practices, Vol. 2018 (2018), Article ID 335906, DOI:10.5171/2018.335906 
project management is seen as the largest effort to transform government through eGovernment efforts (Furlong \& AlKaraghouli, 2010). The transformation to e-Government is a new venture for many African governments. In ICT intensive projects such as e-Government, project managers need to balance the potential benefits against the risk of implementation failure in deciding how much reform (or reengineering) to tackle at any one time (Bhatnagar \& Singh, 2010). By contrast in developed countries, there has been more research focusing on evaluation of Enterprise Architecture frameworks (Liimatainen, Hoffmann, \& Heikkilä, 2007).

In developing countries, scholarly prescriptions for decision support are not always reconcilable with actual practice, giving varying degrees of technical analytical capacity and data quality at the government level (Marcelo, MandriPerrott, House, \& Schwartz, 2015). The research aimed to contribute in determining critical success factors for eGovernment in developing countries using the practical experience of Botswana.

\section{Background}

e-Government is concerned with the delivery of government services to the public through an integrated and interoperable network of legacy systems, enhanced with the latest technology. In it's entirety, e-Government entails the use of Information and Communication Technologies (ICTs) by government in the provision of public services (Joseph, 2017). Enterprise integration is the process of ensuring the interaction between enterprise entities necessary to achieve eGovernment objectives. Enterprise integration can be approached through different architectural domains, Lankhorst (2005) outlines that Enterprise Architecture is the most common coherent method to achieve Enterprise Integration in a consistent manner.

Enterprise integration and underlying systems interoperability aim at facilitating seamless operation between business entities from a single, networked or virtualized organization. While enterprise integration has a strong organizational dimension, interoperability has a more technical nature (Vernadat, 2010). Interoperability still means many things to many people and it is often interpreted in many different ways with different expectations (Chen, 2006). The most common definition comes from the Institute of Electrical and Electronics Engineers (IEEE) where they define interoperability as the ability for two (or more) systems or components to exchange information and to use the information that has been exchanged (Panetto, 2007). Another useful definition of interoperability is by Vernadat (2010) who defines interoperability as the ability for a system to communicate with another system and to use the functionality of the other system. Enterprise interoperability is achieved if the interaction can, at least, take place at the three levels of data, application and business process (Panetto, 2007). The IEEE definition is the most referenced one but it is restricted to information system interoperability. The definition by Vernadat (2010) introduces the concept of exchange of service functionality complementing the IEEE definition. Enterprise interoperability is thus; the ability to communicate and exchange information, use the information exchanged and access to functionality of a third system.

A shared understanding on enterprise interoperability is required for a coordinated and efficient research and development efforts. Without strong interagency coordination and "buy in" the risks of duplication, interoperability gaps, project failure and user dissatisfaction are substantial. By their nature, e-Government systems cut across more than one government functions. Without serious inter-agency coordination, serviceorientation, customer-centric eGovernment is impossible to implement successfully (Ministry of Information and Communications Technology, 2006).

Botswana completed the e-Government Strategy for the period of 2011-2016 in 2010. The key objective was to improve the convenience, quality and efficiency of public sector service delivery by putting 
appropiate services online. To achieve this, the Government envisaged to work as one enterprise - $1 \mathrm{Gov}$ (Botswana Government, 2011). The government needed to integrate information, technologies and structures in order to provide a seamless set of high quality services for clients. To provide a wide choice of delivery channels, Botswana adopted an approach; "any door is the right door".

The goal for the e-government was that once the strategy is fully implemented, clients would access government services through computers and mobile phones, through libraries and Kitsong Centres (or Community Centers) in nearby villages, via a central call centre or a conveniently placed kiosk, in-person at a Government Service Centre, or directly through a ministry office.

In order to link all the components of the framework, a well-connected and stable Government Enterprise Architecture is required (Botswana Government, 2011). The architecture would help to manage complexity and change in business processes such as Records Management, Finance Management, HR \& Payroll, and Geographical Information System (GIS). Existing processes would need reengineering and a group of e-services delivered through a citizen centric government portal. The Interoperability Standards and Stakeholder Engagement Framework will also be developed to support the transformation.

In the report of the Federal government's action plan for e-Government for the United States of America (USA, 2002), the primary goals for the President's "Expanding e-Government" initiative were to: make it easy for citizens to obtain service and interact with the federal government, improve government efficiency and effectiveness and Improve government's responsiveness to citizens. The main goal of the President's vision for reforming government emphasized that "government needs to reform its operations-how it goes about its business and how it treats the people it serves." The following three principles guided the USA vision: citizen-centred, not bureaucracy- centred; results-oriented; and Marketbased, actively promoting innovation.

In the United Arab Emirates, e-Government (UAE) seeked to facilitate the operation of government and the distribution of governmental information and services. The ultimate goal of e-Government as adopted by UAE was to offer an increased portfolio of public services to citizens in an efficient and cost effective manner (AlKhouri, 2012).

In agreement with other governments who have engaged on e-Government, the Kingdom of Bahrain is focused on ensuring effective delivery of government services to citizens, residents, businesses and visitors (considered as not resident customers). The phrase: "Delivering Customer Value through Collaborative Government" summarizes their eGovernment strategy. The main goal of the e-Government strategy was to enhance service delivery through the phased electronic enablement of services, also recognizing that the provision of services through electronic tools is useful only if it facilitates anyone to access services anytime and anywhere in a more convenient manner. A critical success factor for an effective e-Government strategy include identifying customers' preference delivery channels. In line with this, the UAE Government has identified multiple channels to facilitate the delivery of services: e-Government Portal; Mobile Portal; National Contact Centre; E-Services Centres and e-Kiosks (Al-Khouri, 2012).

Critical Success Factors (CSFs) are defined in several ways depending on the purpose for which they are used. The research defines CSFs as "the limited number of areas in which results, if they are satisfactory, will ensure successful competitive performance for the organisation" (Shah, Branganza, Khan, \& Xu, 2005). The CSF approach represents an accepted top-down methodology for corporate strategic planning, and while it identifies few success factors, it highlights key information requirements of top management. In addition, if the critical success factor identified is controllable, management can take certain steps to 
improve potential for success (Shah et al., 2005). This technique has been widely used in many businesses and technology related contexts for over four decades and its use is still common. In the context of this research, CSFs theory is used to pinpoint some areas that are critical for success of the e-Government in Botswana.

Development of an e-Government ecosystem requires close local support in the development of applications and as such a higher maturity of local application development is required. Botswana Government identified opening Government data as an initiative to facilitate an environment to improve the maturity level of application development. Also, due to its wide area with small population, Botswana's e-Government strategy places an emphases on multiple channel delivery especially; service centers and kiosks.

\section{Research Method}

\section{Sample Size}

The data collection focused on the Government Modernisation Office (eGovernment Office) and the ministries who are the key stakeholders in the eGovernment service delivery framework. The selected participants included employees of the Government Modernisation Office (GMO), Chief Systems Analysts from Government ministries and other senior IT officers from departments. The research targeted these participants due to their knowledge of the on-going eGovernment initiative in Botswana and their level of accessibility to the researchers. There were sixteen ministries in Botswana which formed the study population. With a confidence level of $95 \%$ and margin error of $5 \%$, the ideal sample size was 16 respondents.

\section{The Instrument}

The data was collected using different Likert scales to rate decision maker preferences. Likert scales were chosen for their flexibility and fitness of purpose. Likert scales forms the basis of multicriteria decisions analysis (MCDA) methods such as AHP which allows the user to specify their preferences. Users to can rate important choices in a multivariable approach.

In order to determine which of the factors identified were relevant, surveys in the form of questionaire and interviews were mixed as research instruments. The desirability of mixing methods to leverage on strengths and reduce weaknesses found in single method designs, is supported by most text books (Jick, 1979).

The questionnaire was divided into two sections. The first section posed questions specific to the environment needed for the e-Government solutions and the second section focuses on the demography of the interviewees.

The questions specific to e-Government solutions could be divided into basic understanding/impact of e-Government, delivery of e-Government solutions and eGovernment service delivery.

\section{Findings}

Twenty-two respondents participated in the study representing sixteen ministries. Fifty-nine (59\%) of the participants were male, while $41 \%$ were female. In terms of their ages, $5 \%$ of participants were below 30 years, $50 \%$ between 31 and 40 years while $41 \%$ were over 41 years. There was one (1) missing value under the age category. Seventy-seven (77 \%) of the participants had a first degree in Computer Science, and ICT related courses and four percent (4\%) had higher education degrees. There was one (1) missing value under the degree category.

The three sections below describe the findings from the research.

\section{Basic understanding/impact of}

\section{E-Government}

Respondents were asked to rate their overall understanding of e-Government. The responses to the question are depicted in Figure 1. The majority of the respondents rated themselves as having intermediate and advanced understanding 
of e-Government and none rated

themselves as e-Government experts.

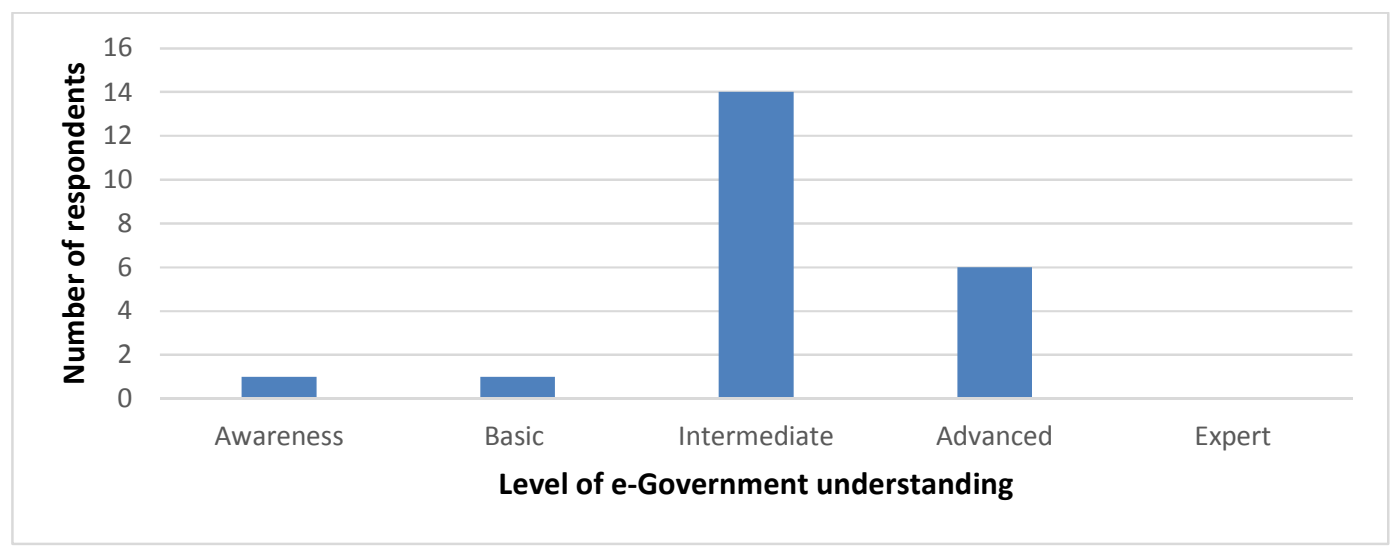

Figure 1: Level of understanding of e-Government

Another question asked was "What is eGovernment?" This question was meant to help establish the level of understanding of the e-Government Project within the agencies implementing e-Government in the Botswana. The question was critical in finding out the understanding of eGovernment among officers responsible for e-Government. The majority of the interviewees described e-Government as the use of ICTs to provide efficient and effective services to government stakeholders. This view is in agreement with another view given by eight (8) interviews who simply said e-Government is the provision of services electronically. Table 1 shows the responses from the participants.

Table 1: Definitions of e-Government

\begin{tabular}{|l|c|}
\hline Question & Summary of data collected from interviews \\
\hline What is e-Government? & - Use of Information and Communication Technologies (ICTs) \\
& to provide efficient and effective services to government \\
& stakeholders \\
- & Provision of Government Services electronically \\
- & The use of internet by Governments to improved service \\
& delivery digital \\
& Enablement of Government to stakeholder deractions \\
& - Electronic Government \\
\hline
\end{tabular}

The next question is a follow-up question to the previous one. It helps identify the expected impact of e-Government solution in Botswana. The question was aimed at finding out what the participants consider as yardstick for measuring whether the eGovernment project was a success or not.
This will help in identifying the critical success factors of e-Government in Botswana. The participants offered a wide variety of what they considered possible envisaged impact of e-Government. The majority of the responses linked the responses to how an e-Government 
solution will make government more efficient, and thus being able to improve the lives of citizens. Table 2 summarizes responses from the questionnaires.

Table 2: Expected impact of e-Government solution

\begin{tabular}{|c|c|}
\hline Question & Summary of data collected from interviews \\
\hline $\begin{array}{l}\text { What is your expected } \\
\text { impact of e-Government } \\
\text { solution in Botswana? }\end{array}$ & 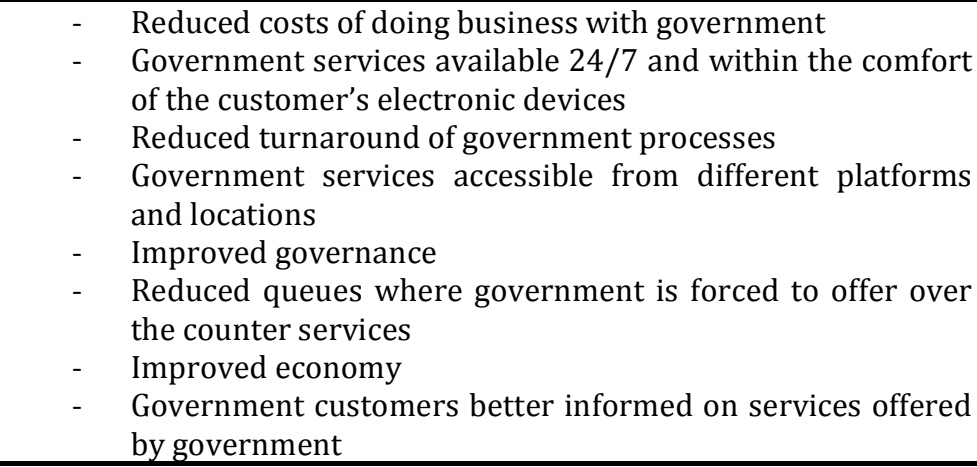 \\
\hline
\end{tabular}

E-Government will improve government services delivery, which will in turn improve the livelihood of Botswana Citizens, visitors and anyone who aspires to interact with the Government

The next question identify the most important digital interaction in eGovernment. The question states that "For an e-Government solution to have the biggest impact, which group of customers/ stakeholders should the solution focus on? "Rank (1 - Most Preferred, 5 - Least Preferred). This question is necessary to identify areas that e-Government project must focus on for it to be considered a success. The answer aims to identify critical success criteria attributes.

Table 3 shows the summarized responses from the questionnaires.

Table 3: Preferred interaction of e-Government solution

\begin{tabular}{|l|l|l|l|l|l|}
\hline Ranking & $\begin{array}{l}\text { Government } \\
\text { Departments }\end{array}$ & $\begin{array}{l}\text { Clients or } \\
\text { customers }\end{array}$ & $\begin{array}{l}\text { Government } \\
\text { Employees }\end{array}$ & Businesses & Other \\
\hline 1 & 3 & 16 & 2 & 3 & 1 \\
\hline 2 & 9 & 0 & 7 & 8 & 0 \\
\hline 3 & 3 & 3 & 9 & 5 & 0 \\
\hline 4 & 6 & 1 & 2 & 5 & 1 \\
\hline 5 & 0 & 1 & 1 & 0 & 0 \\
\hline
\end{tabular}

Government interactions with clients or customers ranked as the most important by the majority of interviews with sixteen (16) ranking it as the most important.
However, for the second and third ranks, results were closely contested with equal votes. 


\section{Delivery of e-Government}

In order to map out e-Government delivery, one of the questions asked was "How should the Government provide $e$ Services to citizens?" This question helped identify the most preferred channel for delivering services by e-Government solution in Botswana. The question established areas where the e-Government solution must focus on in order to have the biggest impact in the lives of citizens and government customers. The result summary is shown in Table 4 on a seven point Likert scale with 1 - most referred and 7 - least preferred.

Table 4: Channels of e-Government service delivery

\begin{tabular}{|l|l|l|l|l|l|l|l|}
\hline Ranking & $\begin{array}{l}\text { Counter } \\
\text { Top }\end{array}$ & $\begin{array}{l}\text { Web } \\
\text { Portal }\end{array}$ & $\begin{array}{l}\text { Mobile } \\
\text { Portal }\end{array}$ & $\begin{array}{l}\text { Contact } \\
\text { Centre }\end{array}$ & $\begin{array}{l}\text { Services } \\
\text { Centre }\end{array}$ & $\begin{array}{l}\text { e- } \\
\text { Kiosks }\end{array}$ & Others \\
\hline 1 & 0 & 16 & 13 & 0 & 3 & 3 & 1 \\
\hline 2 & 0 & 3 & 6 & 5 & 5 & 3 & 1 \\
\hline 3 & 2 & 0 & 0 & 8 & 10 & 5 & 0 \\
\hline 4 & 0 & 0 & 1 & 3 & 3 & 7 & 0 \\
\hline 5 & 1 & 2 & 1 & 6 & 1 & 3 & 0 \\
\hline 6 & 13 & 0 & 0 & 0 & 0 & 0 & 0 \\
\hline 7 & 7 & 1 & 1 & 0 & 0 & 1 & 2 \\
\hline
\end{tabular}

Sixteen (16) participants ranked Web Portal at number one (1) and thirteen (13) participants ranked Mobile Portal as number one (1). AHP allows equally important criteria to be identified and this implies that the 13 responded ranked Web Portal is equally important to Mobile Portal. Web Portal and Mobile Portal are the most favoured delivery channels of eGovernment services whereas services offered over the counter are the least preferred as shown in Table 5

In the question "How should e-Government project be coordinated in Botswana?" the research wanted to find the most preferred mode of coordinating e-Government activities in Botswana. The level of integration of the organisation is always tied to its information base and thus to the enterprise architecture framework it will adopt. Fifteen (15) of the respondents who indicated preference to all e-Government activities are coordinated by a central office. This is analogous to the situation in Botswana where the Government Modernisation Office coordinates all eGovernment activities. However, a smaller but a significant number believes the eGovernment Office should just set the directions, policies and frameworks and then Ministries and other government agencies should have some freedom in how they align with them. Five (5) of the participants preferred a federated eGovernance approach.

Another question asked was "Do you believe your IT organization is helping business deliver required business solutions?" The intent of the question was to identify the amount of gap between the ICT services and business services. It is key in helping to determine if indeed an enterprise architecture framework can be useful when implementing e-Government. From the responses, thirteen (13) interviewees believe that IT is helping government to deliver required solutions, whereas, twelve (12) says it is not helping. The answers indicate there is no clear-cut contribution to service delivery attributed to Information Technology.

During the implementation of Enterprise Architecture, one of the key attributes of an EA framework is minimising wastage of ICT. To minimize ICT costs, implementing organisations used strategies such as reducing duplication of systems, software components reuse, and improving information visibility. One of the key ways to reduce ICT costs is to ensure IT spending 
is business driven instead of technology driven. This was achieved by having IT budgets justification closely tied to business deliverables.

Table 55 shows the summarized responses

Table 5: IT spending justification

\begin{tabular}{|c|c|}
\hline Question & Summary of data collected from interviews \\
\hline $\begin{array}{lcc}\text { How does } & \text { your } & \text { IT } \\
\text { organization } & \text { justify } & \text { IT } \\
\text { spending? } & & \end{array}$ & 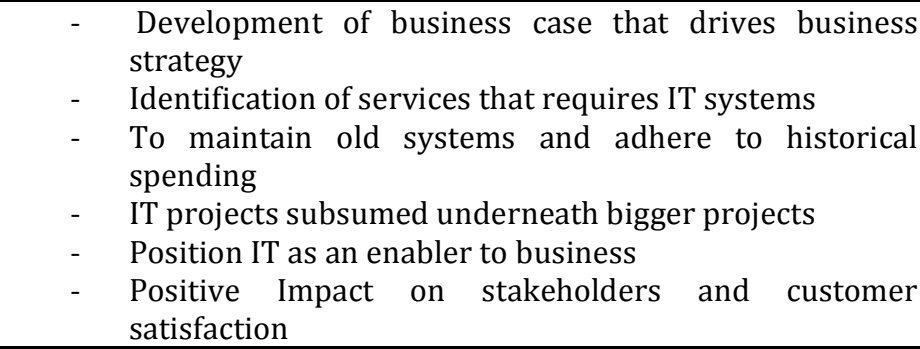 \\
\hline
\end{tabular}

The respondents had a wide variety of issues used to justify spending on ICT and there seems to be no formalized way to link ICT expenditure directly to the operational efficiency and aspirations of e-Government.

\section{E-Government Systems and Service Delivery}

The first question posed in this section was used to perform an environmental

Table 6. The majority of the existing systems were web based, transactional system supporting day-to-day Government scan of systems available within each department. The answers provided were an insight into the ICT landscape for evaluating required Enterprise Architecture frameworks. The question also wanted to identify how systems are currently deployed. The respondents provided a comprehensive list of Government systems and the summary is as shown

in

systems. The environment scan showed that Government Datacentre hosts some government systems but some ministries/departments host their own systems.

Table 6: Types of deployed systems

\begin{tabular}{|c|c|}
\hline Question & Summary of data collected from interviews \\
\hline $\begin{array}{l}\text { List all systems }(\mathrm{s}) \\
\text { deployed in your } \\
\text { department? }\end{array}$ & 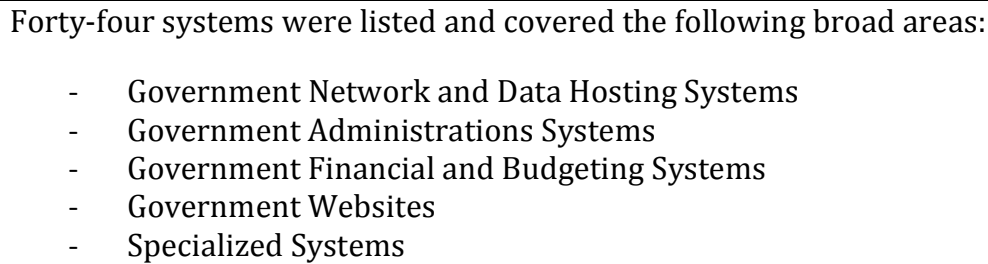 \\
\hline
\end{tabular}

There is a government operated network which facilitates communication of systems. However, similar systems exist at different ministries. The ICT environment contained duplicated systems, data exchange between systems was minimal, and therefore ICT is not aligned to the overall objective of e-Government.

The next question was to help determine how system documentation was 
maintained and shared. One of the key benefits when adopting an EA framework is how much it will assist an organisation on documenting the lifecycle of a system through an effective EA repository. Figure 2 shows that ten (10) of the respondents indicated they are not sure of the storage of their system information.

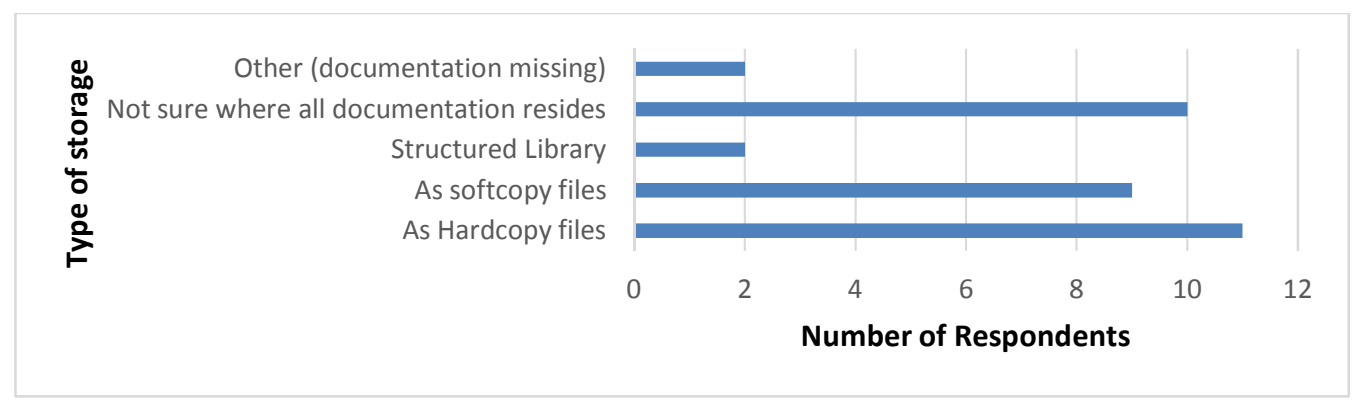

Figure 2: System documentation methods

There seems to be no clear method or format for maintaining documentation of systems within the ministries/department participating in e-Government in Botswana.

Another question posed in this section was - "What drives the introduction of new technology in to your department?" The question helped to identify if adoption of eGovernment systems is technology driven or business driven. Seventeen (17) of respondents indicated that in their departments, business needs drives technology adoption. However, a smaller but significant number of five (5) identified the need to follow technology as a key driver for technology adoption.
A follow-up question was asked to identify how the current maintenance of system documentation affects e-Government systems knowledge transfer in the departments. The question was 'If you were to leave the department, how will your replacement be able to know about core business applications?" The majority of the respondents demonstrated preference to using handover notes and to system documentations for system learning. A smaller number will depend on the business users to facilitate system knowledge transfer to new employees, see Figure 3.

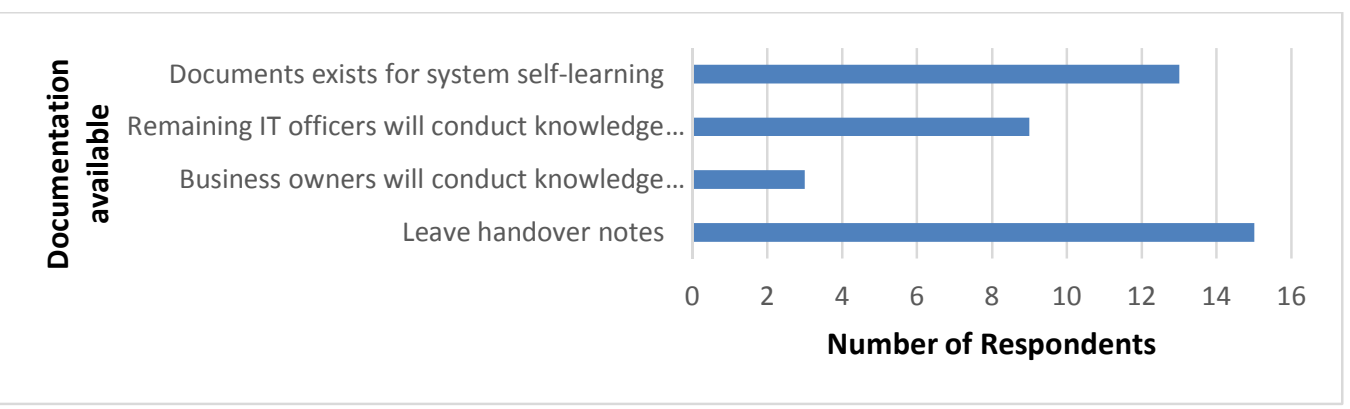

Figure 3: Knowledge transfer strategies

How can systems be improved in order to improve service delivery? With this question, the research aims to find out the most preferred method of system improvement. The question ties to the environmental scan on the status of the systems and their shortcomings in improving service delivery. Modifying existing systems to download or upload information from other systems and re- 
design systems according to new requirements ranked as the most preferred by most of the respondents. However, redesign systems also ranked as the second most preferred method. The introduction of new systems to cover customer requirements generally ranked as the least preferred method for improving systems. The details are shown in Table 7 on a seven point Likert scale with 1 - most referred and 4 - least preferred.

Table 7: Preferred system improvement method

\begin{tabular}{|l|l|l|l|l|}
\hline Rank & Modify Existing Systems & Re-design Systems & New Systems & Other \\
\hline 1 & 11 & 11 & 3 & 1 \\
\hline 2 & 7 & 9 & 3 & 1 \\
\hline 3 & 4 & 1 & 12 & 0 \\
\hline 4 & 0 & 0 & 2 & 0 \\
\hline
\end{tabular}

\section{Discussion}

This section discusses the responses from the questionnaires. The section explains in detail the results of the research, coming up with seven critical success factors and relates them to the key research questions based on theories and ideas from the literature review.

- Basic understanding/impact of e-Government

- Delivery of e-Government

- E-Government Systems and service delivery

\section{Basic understanding/impact of e- Government}

e-Government program is a transformation and as such, engaged transformational Leadership is critical (Saha, 2009). Either the e-Government program can be decentralised with government departments driving their own eGovernment agenda or the efforts can be centrally coordinated. According to this research, the centrally coordinated office is a critical aspect of the success of eGovernment. The coordination should allow implementing agencies some level of autonomy in choosing operational methods that best suits the business line. The central office should focus on the strategies and frameworks that provide a common environment and enable government departments to deliver services to citizens seamlessly. An e-Government Office should provide that set direction for other ministries and agencies for an effective and efficient e-Government transformation. This brings about the first critical success factor - "Engaged e-Government Leadership". Engaged leadership is generally accepted as the main critical success factors for Information Systems (IS) to make lasting impact on organisations. In engaged leadership, which is differentiated from leadership support, the leaders are active participants in adopting the IS. In the context of Botswana, leadership at all levels are expected to actively participate in driving e-Government adoption.

When asked to define the term eGovernment, different respondents had different descriptions of e-Government. The majority of the respondents considered e-Government as the use of ICTs to provide efficient and effective services to government stakeholders. The interviewees offered a practical definition of e-Government, which described the technology behind e-Government solutions such as the use of internet to provide services, enablement of government to stakeholder digital interactions and electronic government. Their definitions could be summarised as "e-Government is the use of ICTs to improve service delivery of government. It involves building digital interactions between government and its stakeholders, customers, business partners, citizens and other governments." The second critical success factor is 
therefore - "Common definition for eGovernment". Adopting a common definition for e-Government would provide more consistency in interpreting and implementing initiatives for e-Government. Since most departments will be engaged in different aspects of similar initiatives, a common definition is critical for realising the common e-Government vision across government.

The expected outcomes of the eGovernment project varied for officers who participated in the interview process. However, the research established a core set of pre-conditions necessary to make an e-Government project in Botswana successful. The interviewees indicated that for the e-Government project to be successful, the e-Government project should lower the cost of doing business with government. The government services should be available $24 / 7$ and accessible for the comfort of the customer's electronic devise from different platforms and locations. Since the systems will be in place to automate government processes, they should reduce turnaround time when doing business with Government. Governance should also improve as eGovernment systems enable government to conduct its business consistently. Most importantly, the research found that a successful e-Government project should have a positive impact on the livelihoods of citizens, as improved service delivery stimulates the economy. The expected outcome from the survey was that it will help improve government service delivery and improve livelihood of Botswana citizens, visitors and anyone who aspires to interact with the Government. The third critical success factor derived from the research was striving for "Common expectations of e-Government". Similar to the importance of Common definition for eGovernment, reaching common expectations of e-Government will allow the providers and beneficiaries of the eGovernment to manage expectations consistently. If the expectations of the eGovernment project are not standardized across the citizens, it becomes difficult to demonstrate the impact made by the eGovernment project. In extreme cases, some citizens will even demand eGovernment to provide services or transformations which are outside the scope of the e-Government project.

\section{Delivery of e-Government}

The e-Government project in Botswana has identified many stakeholders who are key to government interactions. This includes businesses, government departments, customers or citizens and government employees. In order to meet the needs of all stakeholders, the government should implement a complete solution with multiple stakeholder views. According to the interviewees, the e-Government project in Botswana should first focus on one group - the customers. The interaction includes citizens who constitutes the majority of the government customers. Meeting requirements of the clients or customers is the most preferred eGovernment interaction. The fourth critical success factor from the research is therefore a "Customer Centric $e$ Government". Being customer centric will allow Government to quickly deliver impact through the e-Government. This will afford the Government time to focus on the other interactions which are seen as secondary to customers. The factor will act as a basic for phased approach strategy which is critical for large scale projects.

The Government portal is the face of eGovernment project. However, other forms of delivery channels are quickly catching up. Botswana's e-Government strategy calls for a multi-channel service delivery framework for e-Government with the case for mobile solutions being driven by the high penetration of mobile networks and devices (Botswana Government, 2011). In their research, Esselaar and Sebusang (2013) reported that in Botswana, ICT penetration is at $9 \%$ whereas mobile penetration sits at $150 \%$. This observation presents an opportunity to e-Government solutions for providing service delivery via mobile devices. However, this research found that the overwhelming majority of respondents believe that the e-Government project in Botswana must be able to deliver 
services efficiently and effectively through the web portal for it to be a success. Web Portal is the most preferred e-Government delivery channel. This leads to the fifth critical success factor which is a "Functional e-Government Web Portal". The web-portal is expected to be the leading channel for e-Services in Botswana. Despite the research finding out that most people will prefer web-portal, global trends show that mobile solutions have long surpassed web portal. The strategy should be to deploy web portal as a main landing page which provides key information including links to the mobile portals and mobile applications.

Information technology can provide strategic value to governments as they cope with changes by supporting administrative infrastructure, key business and operational processes, and can be used to "reduce costs, enhance product and service quality, improve customer service, integrate supplier and customer operations, and enable organizational learning" (Cane \& McCarthy, 2007). The expenditure for ICT projects must be justified based on business cases that drive the business strategy. Government must identify services that have high impact on citizens and prioritise ICT systems supporting them. The research found the reasons to avoid ICT spending such as following historical spending, maintenance of legacy systems, and embedding ICT under bigger projects. The priority should be on ICT systems that will have the highest impact on service delivery to citizens. The survey shows that there is a need to develop a formalized way to link ICT expenditure directly to the operational efficiency and aspirations of e-Government. This brings the sixth critical success factor that shows that "IT spending is justified in business terms". E-Government is a transformation of business operations through the application of Information Technology. In justifying IT spending, positive transformation of business and service delivery should be the main criteria. This will allow the Government to achieve maximum impact of e-Government and faster customer satisfaction. The approach will also allow Government to earn return on investment (ROI) on IT systems as opposed to chasing the latest technology. The impact of e-Government can also be realised if Government processes are matured through improvements and sharing assets.

\section{E-Government Systems and Service Delivery}

Mainframe computers were introduced in the Accountant General office in the 1960s to support payroll and accounting activities. Information Technology adoption has evolved since then into a government wide ICT infrastructure that helps manage the economy and other public administration functions. Moreover, national IT strategies facilitated the integration of applications in some ministries using a government wide IT framework. An example of these applications is the Government Accounting and Budgeting System (GABS) that manages budgeting and accounting functions for all the central government revenue and expenditure. For this evolution to gain traction and produce real results, this research found that business needs and not technology needs should drive technology adoption. The survey results supported that business needs should be the dominant driver for technology adoption, however, technology opportunities should be considered by some government departments. The last identified critical success factor is focusing on - "Business driven technology adoption". Traditionally technology driven adoption was seen where Information Technology departments were responsible for bringing new technology to the business units as customers. In e-Government, the customers are the citizens who do not interact with the IT department. The new paradigm shift allows the business units to respond to their customer demands. This will require a fundamental change in the placement of IT functions within Government in order for them to facilitate business units to respond to customer demands. IT departments should move towards customers and eliminate the space between themselves and business units. Business driven technology adoption in Government will thus allow Government 
departments to be flexible and agile in provision of e-Government services to citizens.

\section{Conclusion}

The critical success factors are strategic capabilities and conditions necessary to foster success in any project. When adopting enterprise architecture in eGovernment, the implementing organisation must determine CSFs that would ensure success. This research identifies critical success factors needed to make the e-Government organisation ready for implementing e-Government projects such as enterprise architecture. From the research, the following seven critical success factors were derived for eGovernment in Botswana.

- $\quad$ Engaged e-Government Leadership

- Common definition for e-Government

- Common Expectations of eGovernment

- Customer Centric e-Government

- Functional e-Government Web Portal

- IT spending justified on business terms

- Business driven technology adoption

The success factors are a demand side that engages executive management to set a clear vision, prioritizes functional capability and manages stakeholders' expectations.

\section{Acknowledgment}

The research is part of MSc. research for Mr. Christopher Mokone. The authors would like to thank the Ministry of Transport and Communications (MTC) and e-Government Offices in Botswana for allowing this research to be carried out.

\section{References}

1. Al-Khouri, D. A. M. (2012). eGovernment Strategies The Case of the United Arab Emirates (UAE). European Journal of ePractice, 17, pg 126-151.

2. Bhatnagar, S. C., \& Singh, N. (2010). Information Technologies \& International Development, 6(2), 109-127.

3. Botswana Government. (2011). Botswana's National e-Government Strategy 2011-2016. pg. 1-70.
4. Cane, S., \& McCarthy, R. (2007). Measuring the impact of Enterprise Architecture. Issues in Information Systems, VIII(2), pg. 437-443.

5. Chen, D. (2006). Framework for Enterprise Interoperability. Paper presented at the IFAC TC5.3 workshop EI2N06 (Enterprise Integration Interoperability and Networking), Bordeaux France.

6. Esselaar, S., \& Sebusang, S. (2013). Understanding what is happening in ICT in Botswana. Retrieved from ResearchICTAfrica.net

7. Gil-Garcl'a, J. R., \& Pardo, T. A. (2005). Egovernment success factors: Mapping practical tools to theoretical foundations. Government Information Quarterly, 22, pg. 187-216.

8. Joseph, B. K. (2017). Determining Factors Influencing E-Government Development in the Developing World: A Case Study of Zambia. Journal of $e$ Government Studies and Best Practices, 2017, pg. 1-16. doi:10.5171/2017.143795

9. Lankhorst, M. M. (2005). Enterprise architecture modelling-the issue of integration. Advanced Engineering Informatics, 18, pg. $205-217$.

10.Liimatainen, K., Hoffmann, M., \& Heikkilä, J. (2007). Overview of Enterprise Architecture work in 15 countries. Finnish Enterprise Architecture Research Project. pg.1-81.

11.Marcelo, D., Mandri-Perrott, C., House, S., \& Schwartz, J. (2015). Prioritization of Infrastructure Projects: A Decision Support Framework. 1-30.

12.Ministry of Information and Communications Technology. (2006). $e$ Government Strategy. Retrieved from Jordan e-Government:

13.Panetto, H. (2007). Towards a classification framework for interoperability of enterprise applications. International Journal of Computer Integrated Manufacturing, 20(8), pg. 727 740. doi:10.1080/09511920600996419 14.Saha, P. (2009). Advances in Government Enterprise Architecture: IGI Global.

15.Saha, P. (2010a). Enterprise Architecture as a platform for connected government - Advancing the whole-ofgovernment enterprise architecture adoption with strategic (systems) thinking. 
In (pp. pg. 15): NUS Institute of Systems Science.

16.Saha, P. (2010b). Enterprise Architecture as platform for connected government. National University of Singapore,

17.Shah, M. H., Branganza, A., Khan, S., \& $\mathrm{Xu}$, M. (2005). A Survey of Critical Success Factors in e-Banking. European, Mediterranean \& Middle Eastern Conference on Information Systems, pg. 1-16.

18.USA. (2002). Implementing the President's Management Agenda for EGovernment. Retrieved from Office of Management and Budget: http://www.whitehouse.gov/OMB

19.Vernadat, F. B. (2010). Technical, semantic and organizational issues of enterprise interoperability and networking. Annual Reviews in Control, 34, pg. 139-144. doi:https://doi.org/10.1016/j.arcontrol.20 10.02.009 